\title{
Blockade of dopamine activity in the nucleus accumbens impairs learning extinction of conditioned fear
}

\author{
Orit Holtzman-Assif, Vincent Laurent, and R. Frederick Westbrook ${ }^{1}$ \\ School of Psychology, The University of New South Wales, Sydney, New South Wales 2052, Australia
}

\begin{abstract}
Three experiments used rats to investigate the role of dopamine activity in learning to inhibit conditioned fear responses (freezing) in extinction. In Experiment 1, rats systemically injected with the D2 dopamine antagonist, haloperidol, froze more across multiple extinction sessions and on a drug-free retention test than control rats. In Experiment 2, rats extinguished under an intracerebroventricular (ICV) infusion of haloperidol suppressed fear responses across extinction but froze more on a subsequent drug-free retention test than control rats. In Experiment 3, rats extinguished under an infusion of haloperidol in the nucleus accumbens were impaired in suppressing fear responses across extinction and froze more on subsequent drug-free retention test than control rats. These results show that learning to inhibit fear responses in extinction requires dopamine activity in the nucleus accumbens. They were interpreted to mean that dopaminergic activity in the nucleus accumbens regulates the prediction error required for learning to inhibit fear responses in extinction.
\end{abstract}

There has been considerable progress in understanding the neural mechanisms underlying the acquisition of fear responses in laboratory subjects (Blair et al. 2001; Maren 2001; Fanselow and Poulos 2005), but much less is known about the neural mechanisms underlying the extinction of these responses (Delamater 2004; Myers and Davis 2007). Extinction occurs when the signaling relation between a conditioned stimulus (CS; e.g., a noise) and an aversive unconditioned stimulus (US; e.g., footshock) is broken by exposures to the CS in the absence of the US. The fear responses (e.g., freezing) produced by the signaling relation decline across the CS alone exposures and eventually cease to occur. Fear of the CS is said to be extinguished. Various phenomena show that much, if not all, of the original association survives extinction in spite of the fact that the CS fails to elicit fear responses (Bouton et al. 2006). Such phenomena include the "renewal" of fear responses when the CS is tested outside the extinction context; their "reinstatement" when the extinguished CS is tested in the presence of, or shortly after exposure to danger; and their spontaneous recovery when the CS is tested some time after extinction. These phenomena imply that extinction involves new learning which coexists with the old while inhibiting its expression in fear responding (Bouton 1993).

What conditions produce inhibition in extinction? Contemporary psychological models invoke prediction error to explain a range of Pavlovian acquisition phenomena (e.g., overshadowing, blocking, and super conditioning). Such models (Dickinson 1980; Rescorla 1988) hold that the omission of the predicted US constitutes the error which drives the inhibitory association that comes to suppress fear responding in extinction. There is considerable evidence from appetitive conditioning procedures that prediction error is instantiated in the firing of dopamine (DA) neurons in the ventral tegmental area (VTA) (Schultz and Dickinson 2000). These neurons fire in response to an unexpected reward and then cease to fire to that reward concomitantly with an increase in firing to a CS, which signals the reward (Waelti et al. 2001).

\footnotetext{
'Corresponding author.
}

E-mail f.westbrook@unsw.edu.au; fax 61-92-03853044.

Article is online at http://www.learnmem.org/cgi/doi/10.1101//m.1668310.
Moreover, the omission of a predicted reward is accompanied by a suppression of firing at the time when the US normally occurred. There is also evidence from aversive conditioning procedures that DA levels in the nucleus accumbens (Acb) are increased following presentations of an unexpected footshock and that these levels are also increased by a CS which has come to signal the footshock US (Sorg and Kalivas 1991; Young et al. 1993; Guarraci and Kapp 1999; Young 2004). DA activity also appears to play a role in extinction (Pan et al. 2008). For instance, responses of midbrain DA neurons decline across repeated presentation of a CS in a manner that is correlated with the decline of conditioned responding. Moreover, many of these neurons come to show inhibitory responses at the end of extinction, consistent with the inhibitory nature of the learning produced. These findings raise the possibility that dopaminergic activity in the Acb is involved in extinction, potentially regulating some aspect of the prediction error necessary for the development of learned inhibition. However, the role played by Acb DA in learning inhibition in fear extinction is unknown.

The present experiments examined the role played by DA in learning extinction of conditioned fear responses (i.e., freezing; see Blanchard and Blanchard 1969). Seventy-one experimentally naive male Wistar rats (Gore Hill Research Laboratories, Sydney, New South Wales, Australia) were used. They were kept in a climate-controlled colony room under natural lighting. Seven days after arrival in the laboratory, rats were handled each day for $4 \mathrm{~d}$. On day 1 of Experiment 1, rats were placed in conditioning chambers and were trained to fear a clicker CS $(30 \mathrm{sec}, 75 \mathrm{~dB})$ that co-terminated with a footshock US ( $1 \mathrm{sec}, 0.6 \mathrm{~mA})$. There were four pairings of the clicker CS and the footshock US. On day 2, rats were injected i.p. with either vehicle (Groups Extinction: $0 \mathrm{mg} / \mathrm{kg}[n=$ 10] and No-extinction: $0 \mathrm{mg} / \mathrm{kg}[n=8])$ or one of the three doses of haloperidol (Groups Extinction: $0.05 \mathrm{mg} / \mathrm{kg}[n=6]$, Extinction: $0.1 \mathrm{mg} / \mathrm{kg}[n=7]$, Extinction: $1 \mathrm{mg} / \mathrm{kg}[n=6]$, and No-extinction: $0.1 \mathrm{mg} / \mathrm{kg}[n=8]$ ) selected on the basis of previous research (Joseph et al. 2000; Shadach et al. 2000). Forty-five minutes later, rats in Groups Extinction received an extinction session in which they were placed in the conditioning chambers and presented 2 min later with the clicker CS for $5 \mathrm{~min}$ in the absence of the footshock 
US. Rats in the control groups (Group No-extinction) were simply handled. These procedures were repeated on days 3 and 4 . On day 6 , all rats were tested drug-free. Two minutes after placement in the chambers, rats were presented with the CS for $10 \mathrm{~min}$ in the absence of the footshock US.

Levels of freezing to the clicker CS across extinction and test are shown in Figure 1. In this and the remaining experiments, the

A

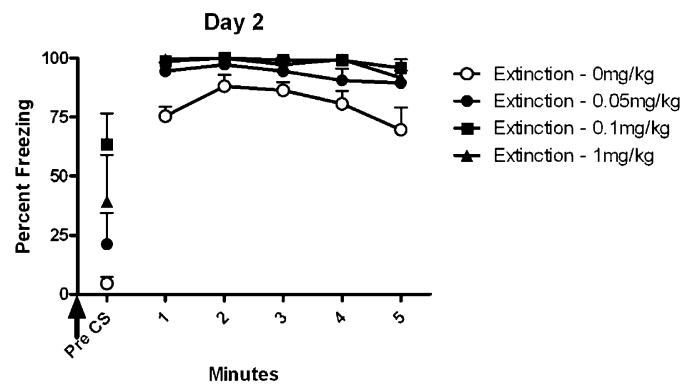

B

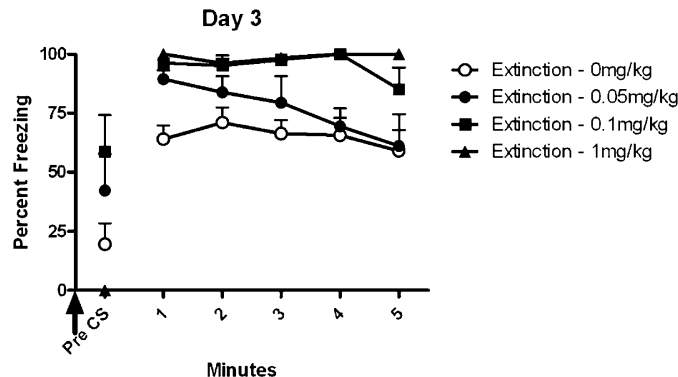

C

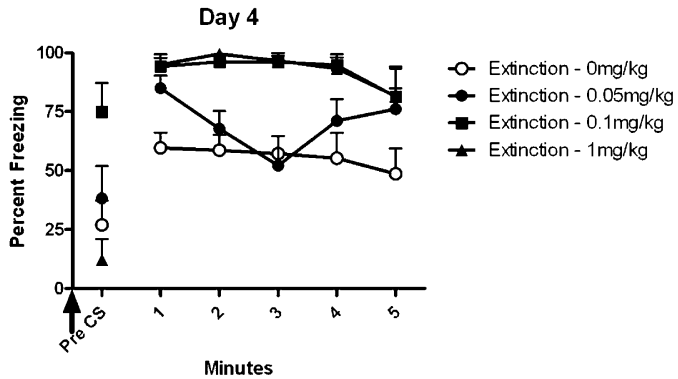

D

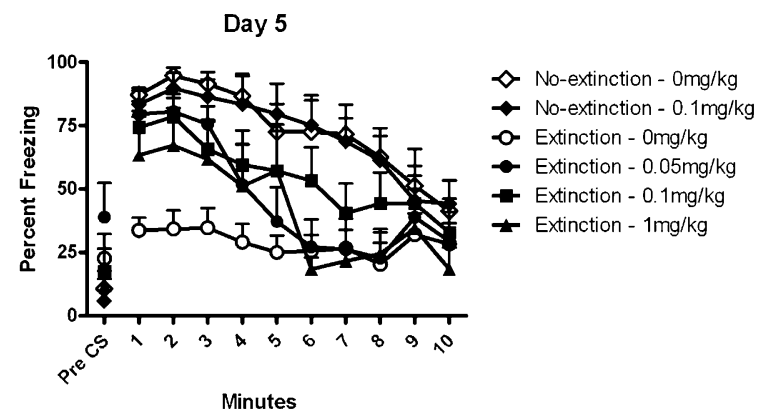

Figure 1. Systemic haloperidol impairs extinction of conditioned fear. All illustrations show the mean and SEM levels of freezing. $(A-C)$ Control rats (Group Extinction: $0 \mathrm{mg} / \mathrm{kg}$ ) suppressed freezing responses across the three extinction sessions. Haloperidol impaired the suppression of freezing responses (Groups Extinction: $0.05 \mathrm{mg} / \mathrm{kg}$, Extinction: $0.1 \mathrm{mg} / \mathrm{kg}$, and Extinction: $1 \mathrm{mg} / \mathrm{kg}$ ). (D) The retention test showed that haloperidol (Groups Extinction: $0.05 \mathrm{mg} / \mathrm{kg}$, Extinction: $0.1 \mathrm{mg} / \mathrm{kg}$, and Extinction: $1 \mathrm{mg} / \mathrm{kg}$ ) impaired long-term retention of extinction. data were analyzed by a set of planned contrasts that controlled the error rate using the Bonferroni inequality procedure $(\alpha=0.05)$. Conditioning on day 1 was successful: All rats exhibited substantial levels of freezing when exposed to the clicker on day 2 (Fig. 1A). Haloperidol impaired extinction. Rats treated with the D2 antagonist froze significantly more across the first extinction session on day 2 (Fig. 1A) than vehicle-treated rats $\left(F_{(1,25)}=27.24, P<0.05\right)$. Rats that received the two highest doses of haloperidol froze at similar levels $\left(F_{(1,25)}=0.4, P>0.05\right)$, and these levels did not differ from those by rats given the lowest dose $\left(F_{(1,25)}=1.4, P>0.05\right)$. The next two extinction sessions on days 3 and 4 (Fig. 1 B,C) confirmed that haloperidol impaired extinction in a dose-dependent manner. Rats injected with the drug froze significantly more across the two sessions than vehicle-treated rats $\left(F_{(1,25)}=45.2, P<0.05\right.$ and $F_{(1,25)}=$ $20.7, P<0.05)$. Rats that received the two highest doses of haloperidol froze at similar levels $\left(F_{(1,25)}=0.6, P>0.05\right.$ and $F_{(1,25)}=0$, $P>0.05)$, and these levels were significantly more than those by rats given the lowest dose (Group Extinction: $0.05 \mathrm{mg} / \mathrm{kg} ; F_{(1,25)}=18.6$, $P<0.05$ and $\left.F_{(1,25)}=7.5, P<0.05\right)$. The overall levels of freezing declined from day 2 to day $4\left(F_{(1,25)}=20.4, P<0.05\right)$.

The impairment in extinction on day 1 could have been due to potentiation of freezing responses among haloperidol-treated rats as they froze significantly more in the pre-CS period than vehicle-treated rats $\left(F_{(1,25)}=9.5, P<0.05\right)$. However, this difference in freezing was absent on days 3 and $4\left(F_{(1,25)}=0.9, P>0.05\right.$ and $\left.F_{(1,25)}=0.1, P>0.05\right)$. A detailed analysis of the pre-CS period on these days revealed that rats in Group Extinction $1 \mathrm{mg} / \mathrm{kg}$ froze significantly less than rats in Group Extinction $0.1 \mathrm{mg} / \mathrm{kg}\left(F_{(1,25)}=\right.$ $14.7, P<0.05$ and $\left.F_{(1,25)}=15.7, P<0.05\right)$. This suggests that pre-CS freezing cannot account for the impairment in CS extinction as both doses impaired that extinction. Further, rats in Group Extinction $0.05 \mathrm{mg} / \mathrm{kg}$ froze just as much as rats that received the two higher doses of haloperidol in the pre-CS period on days 3 and 4 but nevertheless froze less to the CS than rats given the higher doses.

The test data (Fig. 1D) show that systemic injection of haloperidol had impaired long-term retention of any inhibition acquired across extinction. Rats that had not received extinction (Groups No-extinction) froze significantly more than all the other groups of rats $\left(F_{(1,39)}=16, P<0.05\right)$. The injection of haloperidol by itself was without effect since rats in Groups No-extinction showed equivalent levels of freezing whether they had been injected with saline or haloperidol but in the absence of extinction $\left(F_{(1,39)}=0.1, P>0.05\right)$. Rats in Group Extinction-Vehicle froze significantly less than rats extinguished under the drug (Groups Extinction $0.05 \mathrm{mg} / \mathrm{kg}$, Extinction $0.1 \mathrm{mg} / \mathrm{kg}$, and Extinction $1 \mathrm{mg} / \mathrm{kg})\left(F_{(1,39)}=12.5, P<0.05\right)$. But there were no statistically significant differences between the levels of freezing among the rats extinguished under the lowest versus the two higher doses $\left(F_{(1,39)}=0.1, P>0.05\right)$ or between rats extinguished under the two higher doses, $\left(F_{(1,39)}=0.2, P>0.05\right)$. Rats in Group Extinction 0.05 $\mathrm{mg} / \mathrm{kg}$ froze significantly more than all the other groups of rats in the pre-CS period on test $\left(F_{(1,39)}=10.4, P<0.05\right)$, but there were no significant differences among the remaining groups $(F \mathrm{~s}<4)$.

Experiment 1 showed that systemic haloperidol impaired the inhibition of fear responses in extinction and retention of that inhibition. Experiment 2 examined whether the impairment produced by haloperidol was observed when the drug was infused into the brain. Under anesthesia, rats were implanted with cannula in the right ventricle $(\mathrm{AP}=-0.8 ; \mathrm{ML}=+1.5 ; \mathrm{DV}=-4)$. Following one week for recovery from surgery, rats were trained to fear the clicker CS on day 1 in the manner described. On day 2, rats were infused in the ventricle with either vehicle $(2 \mu \mathrm{L})$ (Group Extinction-Vehicle, $n=6$ ) or haloperidol $(2 \mu \mathrm{g} / 2 \mu \mathrm{L}$ ) (Group Extinction-Haloperidol, $n=7$ ). Fifteen minutes later, rats received an extinction session. This consisted in placing the rats in the 
conditioning chambers and, 2 min later, presenting the CS for $10 \mathrm{~min}$ in the absence of the US. On day 4, all rats were tested drug-free in the chambers. Two minutes after placement in the chambers, rats were presented with the CS for $5 \mathrm{~min}$ in the absence of the US.

Levels of freezing to the clicker CS across extinction and test are shown in Figure 2. Conditioning on day 1 was successful as all rats exhibited substantial levels of freezing when presented with the clicker on day 2 (Fig. 2A). Haloperidol did not affect fear responses across extinction. Rats infused with haloperidol into the ventricle froze just as much as did rats infused with vehicle $\left(F_{(1,11)}=0.3, P>0.05\right)$. Overall levels of freezing significantly decreased across the extinction session $\left(F_{(1,11)}=74.9, P<0.05\right)$.

The test data (Fig. 2B) show that intracerebroventricular (ICV) infusion of haloperidol had impaired the retention of the inhibition produced by the CS-alone exposure. Rats that had been extinguished to the CS under haloperidol froze significantly more than rats extinguished under vehicle $\left(F_{(1,11)}=8.4, P<0.05\right)$. There were no statistically significant differences between the groups in the period prior to the presentation of the CS on test $\left(F_{(1,11)}=0.8\right.$, $P>0.05)$.

Experiment 2 showed that an ICV infusion of the DA antagonist impaired retention of inhibitory learning. Experiment 3 examined whether the Acb constituted one of the sites at which the drug had acted to impair retention. The procedure was identical to that used in Experiment 2, except that rats were infused bilaterally in the $\mathrm{Acb}(\mathrm{AP}=+1.4 ; \mathrm{ML}= \pm 1.5 ; \mathrm{DV}=-7)$ with either vehicle $(0.25 \mu \mathrm{L}$ per side) or haloperidol $(0.25 \mu \mathrm{g} / 0.25 \mu \mathrm{L}$ per side) before the extinction session on day 2 .

Levels of freezing to the clicker CS across extinction and on test are shown in Figure 3. Conditioning on day 1 was successful as all rats froze when re-exposed to the CS on day 2 (Fig. 3B).

A

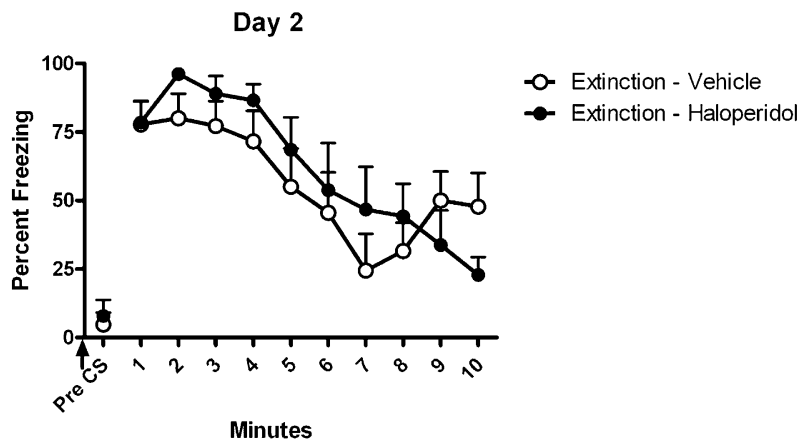

B

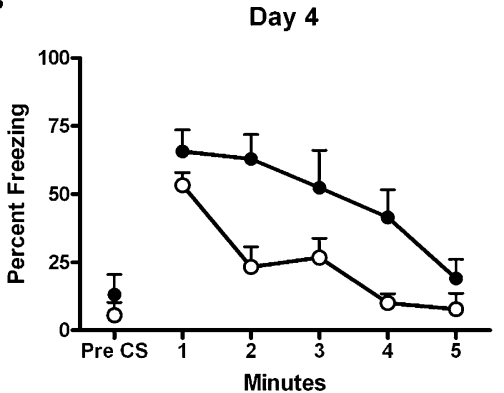

Figure 2. ICV haloperidol impairs extinction of conditioned fear. All illustrations show the mean and SEM levels of freezing. (A) All rats suppressed freezing responses across extinction. $(B)$ The retention test showed that ICV infusion of haloperidol (Group Extinction-Haloperidol) impaired long-term retention of extinction.
Haloperidol impaired the depressive effects of extinction. Rats in Group Extinction-Haloperidol $(n=6)$ froze significantly more than rats in Group Extinction-Vehicle $\left(n=7 ; F_{(1,11)}=5.1, P<0.05\right)$. Overall levels of freezing significantly decreased across the extinction session $\left(F_{(1,11)}=5.3, P<0.05\right)$. Haloperidol-treated rats froze at similar levels as did rats treated with vehicle in the period prior to presentation of the clicker on day $2\left(F_{(1,11)}=2.9, P>0.05\right)$.

The retention test data (Fig. $3 \mathrm{C}$ ) show that intra-accumbal infusion of haloperidol impaired retention of inhibition. Rats extinguished under the drug froze significantly more on the retention test than rats extinguished under vehicle $\left(F_{(1,11)}=17.3, P<0.05\right)$. There were no statistically significant differences between the groups in the period prior to presentation of the clicker CS on test $\left(F_{(1,11)}=0.9, P>0.05\right)$.

The present series of experiments examined the role of dopaminergic activity in learning to inhibit conditioned fear responses in extinction. In Experiment 1, rats that received systemic injection of the D2 DA antagonist, haloperidol, before extinction showed more fear responses across a subsequent drug-free test than rats injected with vehicle. The drug impaired retention of inhibition across each of the three doses used. The drug per se did not elevate the test levels of freezing since control rats injected with the drug but not subjected to extinction did not differ across test from vehicle-injected rats not subjected to extinction. However, haloperidol-treated rats showed more freezing across each of the extinction sessions than control rats, suggesting that the drug had acted to either potentiate freezing or block the development of its inhibition. Alternatively, rats extinguished under the drug may have shown substantial levels of freezing on test not because inhibition was impaired but because of generalization decrement between the drug cues present across extinction and their absence on test, that is, because of state dependency of the learning (Overton 1985). However, the D2 DA antagonist was administered before each of the three extinction sessions conducted across consecutive days. Thus, the second and third sessions can be viewed as a retention test in the presence of haloperidol for the inhibition learned the previous day. These tests also showed that haloperidol impaired retention of inhibition. Further, the next two experiments clearly rule out a critical role for either a potentiation of fear responses or state dependency in the impairment of inhibition produced by haloperidol. In Experiment 2, rats infused before extinction with the D2 DA antagonist in the right ventricle froze more than control rats across the drug-free test given the following day. Importantly, those haloperidol-treated rats froze just as much as control rats across extinction, suggesting that DA activity is involved in consolidation of inhibition. Experiment 3 extended these findings by showing that dopaminergic activity in the nucleus accumbens is particularly important for extinction. Rats that received Acb infusion of haloperidol exhibited more freezing across extinction than control rats and also more freezing across the subsequent drug-free test. Thus, accumbal DA appears to be critical for learning to inhibit conditioned fear responses in extinction and for retaining that inhibition.

The finding that accumbal DA activity regulates the development and retention of the fear inhibition produced by extinction is consistent with its proposed role in predictive learning (Schultz and Dickinson 2000). Contemporary learning theories use error correction mechanisms of one sort or another to explain a range of acquisition phenomena. Such theories also hold that the omission of the predicted US constitutes the error which drives the inhibitory association that comes to suppress fear responding in extinction (Dickinson 1980; Rescorla 1988). The present experiments suggest that changes in the levels of DA in the nucleus accumbens are involved in coding for this error or in transmitting the error signal into other brain regions. This suggestion is consistent with a recent study investigating the role of 
Role of dopamine in fear extinction

A

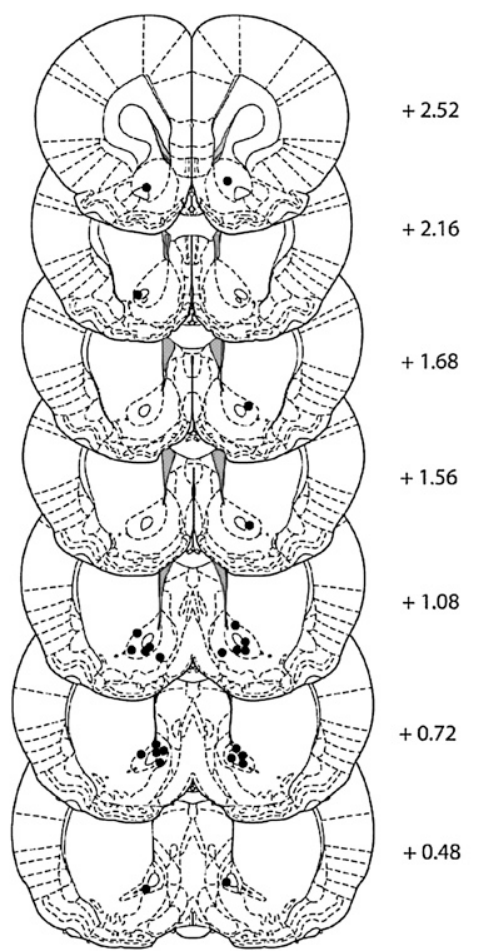

B

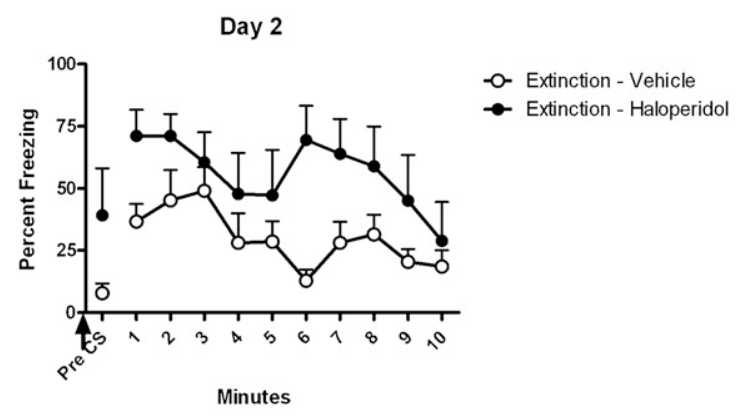

C

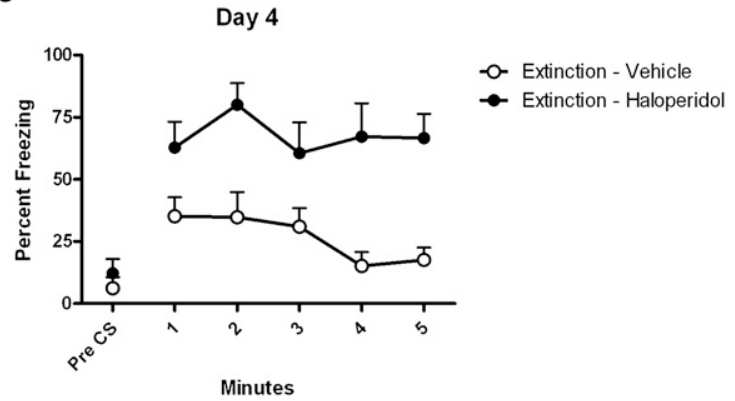

Figure 3. Acb infusion of haloperidol impairs extinction of conditioned fear. $(A)$ Location of cannulae in the nucleus accumbens is shown for all rats included in the final analysis of Experiment 3. Distances on the atlas templates (adapted from Paxinos and Watson [2007] and reprinted with permission from Elsevier (02007) are indicated in millimeters from bregma. (B) Control rats (Group Extinction-Vehicle) suppressed freezing responses across extinction. Haloperidol impaired the suppression of freezing responses across extinction (Groups Extinction-Haloperidol). (C) The retention test data showed that accumbal infusion of haloperidol impaired long-term retention of extinction (Groups Extinction-Haloperidol).

midbrain DA in extinction of appetitive conditioning (Pan et al. 2008). It revealed that the activity of these neurons declines across repeated presentation of the $\mathrm{CS}$ in a manner that is correlated with the decline of the conditioned response. Moreover, many of these neurons came to show inhibitory responses at the end of extinction, consistent with the inhibitory learning assumed to underlie the suppression of responding across extinction. Although these results were obtained in DA neurons located in the VTA, our results provide evidence that accumbal DA also modulates predictive learning in extinction. For example, the local infusion of haloperidol may have prevented the development of inhibitory responses in accumbal DA neurons and thereby impaired extinction of conditioned fear responses.

Regardless of these suggestions concerning its role in prediction error, the present experiments clearly show that DA in the nucleus accumbens is critical for learning and retention of the inhibition produced by fear extinction. However, a currently popular neural model (Quirk and Mueller 2008) does not incorporate a role for the nucleus accumbens in learning extinction. This model attributes extinction to interactions among several structures, but most notably the BLA and the mPFC. Specifically, acquisition and consolidation of the inhibition formed in extinction requires activity in the BLA (Lin et al. 2003; Herry et al. 2006; Kim et al. 2007; Sotres-Bayon et al. 2007, 2009; Laurent and Westbrook 2008; Laurent et al. 2008). In contrast, the infralimbic (IL) subregion of the $\mathrm{mPFC}$ is required for consolidation and retrieval of that inhibition (Quirk et al. 2000; Milad and Quirk 2002; Santini et al. 2004; Hugues et al. 2006; Sierra-Mercado et al. 2006; Burgos-Robles et al. 2007; Laurent and Westbrook 2008, 2009; Sotres-Bayon et al. 2009). Further, the IL is held to suppress fear responses to an extinguished CS through projections to a network of inhibitory interneurons located between the BLA and the CeA (Pare and Smith 1993; McDonald 1998; Royer et al. 1999). Lesioning these interneurons disrupts the expression of extinction (Likhtik et al. 2008), and electrical stimulation of the IL reduces fear responses as well as the activity of CeA neurons that are responsible for eliciting those responses (Vidal-Gonzalez et al. 2006). This model is consistent with much of the available data on extinction, but needs to be extended to include the error correction mechanisms that regulate inhibitory learning in fear extinction. Our results indicate that such mechanisms may involve changes in accumbal DA. The Acb receives projections from both the BLA and the mPFC and is also a major target for DA neurons originating in the VTA (Groenewegen et al. 1990, 1999; Wright et al. 1996). This connectivity suggests that the Acb receives information about the CS from both cortical regions and the BLA, as well as information about the outcome of the CS presentation from the VTA. Accordingly, the Acb may function as a device that holds information about the CS that is then processed differently depending on the error signal provided by DA activation. It is noteworthy that the Acb sends indirect projections to both the BLA, where the initial inhibition is encoded, and the IL cortex, where it is stored (Groenewegen et al. 1990, 1999; Wright et al. 1996). Thus, the release of DA into the Acb may regulate interactions between the BLA and the MPFC that are necessary for learning inhibition in extinction.

\section{References}

Blair HT, Schafe GE, Bauer EP, Rodrigues SM, LeDoux JE. 2001. Synaptic plasticity in the lateral amygdala: A cellular hypothesis of fear conditioning. Learn Mem 8: 229-242. 
Blanchard RJ, Blanchard DC. 1969. Crouching as an index of fear. J Comp Physiol Psychol 67: 370-375.

Bouton ME. 1993. Context, time, and memory retrieval in the interference paradigms of Pavlovian learning. Psychol Bull 114: 80-99.

Bouton ME, Westbrook RF, Corcoran KA, Maren S. 2006. Contextual and temporal modulation of extinction: Behavioral and biological mechanisms. Biol Psychiatry 60: 352-360.

Burgos-Robles A, Vidal-Gonzalez I, Santini E, Quirk GJ. 2007. Consolidation of fear extinction requires NMDA receptor-dependent bursting in the ventromedial prefrontal cortex. Neuron 53: 871-880.

Delamater AR. 2004. Experimental extinction in Pavlovian conditioning: Behavioural and neuroscience perspectives. Q J Exp Psychol B 57: 97-132.

Dickinson A. 1980. Contemporary animal learning theory. Cambridge University Press, Cambridge, UK.

Fanselow MS, Poulos AM. 2005. The neuroscience of mammalian associative learning. Annu Rev Psychol 56: 207-234.

Groenewegen HJ, Berendse HW, Wolters JG, Lohman AH. 1990. The anatomical relationship of the prefrontal cortex with the striatopallidal system, the thalamus and the amygdala: Evidence for a parallel organization. Prog Brain Res 85: 95-116. discussion 116-118.

Groenewegen HJ, Wright CI, Beijer AV, Voorn P. 1999. Convergence and segregation of ventral striatal inputs and outputs. Ann N Y Acad Sci 877: 49-63.

Guarraci FA, Kapp BS. 1999. An electrophysiological characterization of ventral tegmental area dopaminergic neurons during differential pavlovian fear conditioning in the awake rabbit. Behav Brain Res 99: 169-179.

Herry C, Trifilieff P, Micheau J, Luthi A, Mons N. 2006. Extinction of auditory fear conditioning requires MAPK/ERK activation in the basolateral amygdala. Eur J Neurosci 24: 261-269.

Hugues S, Chessel A, Lena I, Marsault R, Garcia R. 2006. Prefrontal infusion of PD098059 immediately after fear extinction training blocks extinction-associated prefrontal synaptic plasticity and decreases prefrontal ERK2 phosphorylation. Synapse 60: 280-287.

Joseph MH, Peters SL, Moran PM, Grigoryan GA, Young AM, Gray JA. 2000. Modulation of latent inhibition in the rat by altered dopamine transmission in the nucleus accumbens at the time of conditioning. Neuroscience 101: 921-930.

Kim J, Lee S, Park H, Song B, Hong I, Geum D, Shin K, Choi S. 2007. Blockade of amygdala metabotropic glutamate receptor subtype 1 impairs fear extinction. Biochem Biophys Res Commun 355: 188-193.

Laurent V, Westbrook RF. 2008. Distinct contributions of the basolateral amygdala and the medial prefrontal cortex to learning and relearning extinction of context conditioned fear. Learn Mem 15: 657-666.

Laurent V, Westbrook RF. 2009. Inactivation of the infralimbic but not the prelimbic cortex impairs consolidation and retrieval of fear extinction. Learn Mem 16: 520-529.

Laurent V, Marchand AR, Westbrook RF. 2008. The basolateral amygdala is necessary for learning but not relearning extinction of context conditioned fear. Learn Mem 15: 304-314.

Likhtik E, Popa D, Apergis-Schoute J, Fidacaro GA, Pare D. 2008. Amygdala intercalated neurons are required for expression of fear extinction. Nature 454: 642-645.

Lin CH, Yeh SH, Lu HY, Gean PW. 2003. The similarities and diversities of signal pathways leading to consolidation of conditioning and consolidation of extinction of fear memory. J Neurosci 23: 8310-8317.

Maren S. 2001. Neurobiology of Pavlovian fear conditioning. Annu Rev Neurosci 24: 897-931.

McDonald AJ. 1998. Cortical pathways to the mammalian amygdala. Prog Neurobiol 55: 257-332.
Milad MR, Quirk GJ. 2002. Neurons in medial prefrontal cortex signal memory for fear extinction. Nature 420: 70-74.

Myers KM, Davis M. 2007. Mechanisms of fear extinction. Mol Psychiatry 12: $120-150$.

Overton DA. 1985. Contextual stimulus effects of drugs and internal states. Erlbaum, Hillsdale, NJ.

Pan WX, Schmidt R, Wickens JR, Hyland BI. 2008. Tripartite mechanism of extinction suggested by dopamine neuron activity and temporal difference model. J Neurosci 28: 9619-9631.

Pare D, Smith Y. 1993. The intercalated cell masses project to the central and medial nuclei of the amygdala in cats. Neuroscience 57: 1077-1090.

Paxinos G, Watson C. 2007. The rat brain in stereotaxic coordinates. Academic, Sydney, Australia.

Quirk GJ, Mueller D. 2008. Neural mechanisms of extinction learning and retrieval. Neuropsychopharmacology 33: 56-72.

Quirk GJ, Russo GK, Barron JL, Lebron K. 2000. The role of ventromedial prefrontal cortex in the recovery of extinguished fear. J Neurosci 20: $6225-6231$.

Rescorla RA. 1988. Behavioral studies of Pavlovian conditioning. Annu Rev Neurosci 11: 329-352.

Royer S, Martina M, Pare D. 1999. An inhibitory interface gates impulse traffic between the input and output stations of the amygdala. J Neurosci 19: $10575-10583$.

Santini E, Ge H, Ren K, Pena de Ortiz S, Quirk GJ. 2004. Consolidation of fear extinction requires protein synthesis in the medial prefrontal cortex. J Neurosci 24: 5704-5710.

Schultz W, Dickinson A. 2000. Neuronal coding of prediction errors. Annu Rev Neurosci 23: 473-500.

Shadach E, Gaisler I, Schiller D, Weiner I. 2000. The latent inhibition model dissociates between clozapine, haloperidol, and ritanserin. Neuropsychopharmacology 23: 151-161.

Sierra-Mercado D Jr, Corcoran KA, Lebron-Milad K, Quirk GJ. 2006. Inactivation of the ventromedial prefrontal cortex reduces expression of conditioned fear and impairs subsequent recall of extinction. Eur $J$ Neurosci 24: 1751-1758.

Sorg BA, Kalivas PW. 1991. Effects of cocaine and footshock stress on extracellular dopamine levels in the ventral striatum. Brain Res 559: 29-36.

Sotres-Bayon F, Bush DE, LeDoux JE. 2007. Acquisition of fear extinction requires activation of NR2B-containing NMDA receptors in the lateral amygdala. Neuropsychopharmacology 32: 1929-1940.

Sotres-Bayon F, Diaz-Mataix L, Bush DE, LeDoux JE. 2009. Dissociable roles for the ventromedial prefrontal cortex and amygdala in fear extinction: NR2B contribution. Cereb Cortex 19: 474-482.

Vidal-Gonzalez I, Vidal-Gonzalez B, Rauch SL, Quirk GJ. 2006. Microstimulation reveals opposing influences of prelimbic and infralimbic cortex on the expression of conditioned fear. Learn Mem 13: 728-733.

Waelti P, Dickinson A, Schultz W. 2001. Dopamine responses comply with basic assumptions of formal learning theory. Nature 412: 43-48.

Wright CI, Beijer AV, Groenewegen HJ. 1996. Basal amygdaloid complex afferents to the rat nucleus accumbens are compartmentally organized. J Neurosci 16: 1877-1893.

Young AM. 2004. Increased extracellular dopamine in nucleus accumbens in response to unconditioned and conditioned aversive stimuli: Studies using $1 \mathrm{~min}$ microdialysis in rats. J Neurosci Methods 138: 57-63.

Young AM, Joseph MH, Gray JA. 1993. Latent inhibition of conditioned dopamine release in rat nucleus accumbens. Neuroscience 54: 5-9.

Received October 13, 2009; accepted in revised form December 7, 2009. 


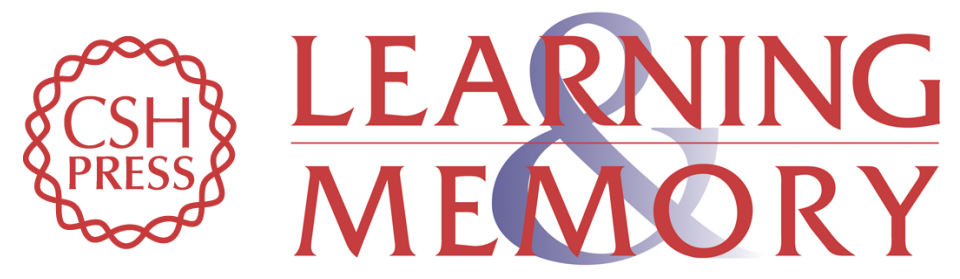

\section{Blockade of dopamine activity in the nucleus accumbens impairs learning extinction of conditioned fear}

Orit Holtzman-Assif, Vincent Laurent and R. Frederick Westbrook

Learn. Mem. 2010, 17:

Access the most recent version at doi:10.1101//m.1668310

References This article cites 41 articles, 11 of which can be accessed free at:

http://learnmem.cshlp.org/content/17/2/71.full.html\#ref-list-1

License

Email Alerting Receive free email alerts when new articles cite this article - sign up in the box at the Service top right corner of the article or click here. 